\title{
From the Roman Empire to Rio de Janeiro: society and models of sustainable water management
}

\author{
Do Império Romano ao Rio de Janeiro: a sociedade \\ e os modelos sustentáveis de gestão das águas
}

\author{
Mauro Alexandre de Oliveira Prioste ${ }^{a}$ \\ Rosa Maria Formiga Johnsson ${ }^{b}$ \\ Alfredo Akira Ohnuma Júnior ${ }^{c}$
}

a Master in Environmental Engineering, PhD student, Universidade do Estado do Rio de Janeiro, Rio de Janeiro, RJ, Brazil E-mail: oprioste@gmail.com

${ }^{b}$ PhD in Environmental Sciences and Techniques, Professor, Departamento de Engenharia Sanitária e do Meio Ambiente, Universidade do Estado do Rio de Janeiro, RJ, Brazil E-mail: formiga.uerj@gmail.com

c PhD in Environmental Engineering, Professor, Doutorado em Engenharia Ambiental, Universidade do Estado do Rio de Janeiro, Rio de Janeiro, RJ, Brazil E-mail: akira@eng.uerj.br

doi:10.18472/SustDeb.v12n2.2021.38769

Received: 30/06/2021

Accepted: 01/08/2021

ARTICLE - VARIA

\begin{abstract}
The purpose of this article is to carry out a content analysis around the historical influence of ancient societies' ideas regarding sustainable water management. Ancient civilizations developed models and practices for the drainage, intake and transport of rainwater and wastewater. Despite the Roman Empire and the Moorish domination, Lisbon maintained its characteristics until the formation of the Kingdom of Portugal, undergoing an urban and sanitary revolution, which lasted until the $19^{\text {th }}$ Century, when the Portuguese Royal Family moved to Brazil. Rio de Janeiro was chosen as the capital of the Kingdom of Portugal, undergoing several alterations inherited from the models and practices of irrigation techniques, hydraulic engineering and architecture of Lisbon. Data compilation in electronic spreadsheets and the use of NVivo software facilitated organizing the information and conclude that sustainable management models can be replicated as an inheritance of ancient societies.
\end{abstract}

Keywords: Roman Empire. The Kingdom of Portugal. Rio de Janeiro. Water Management. Sustainability. 


\section{RESUMO}

O objetivo deste artigo é realizar uma análise de conteúdo da influência histórica dos pensamentos das sociedades antigas em relação à gestão sustentável das águas das chuvas. As antigas civilizações desenvolveram modelos e práticas de drenagem, captação e transporte das águas pluviais e águas servidas. Apesar do Império Romano e da dominação moura, Lisboa manteve suas características até a formação do Reino de Portugal, passando por uma revolução urbanística e sanitária, que se estendeu até o século XIX, quando a Família Real Portuguesa mudou para o Brasil. O Rio de Janeiro foi escolhido como a capital do Reino de Portugal, sofrendo diversas transformações herdadas dos modelos e práticas das técnicas de irrigação, engenharia hidráulica e arquitetura de Lisboa. A compilação de dados em planilhas eletrônicas e o uso do software NVivo facilitaram a organização das informações, concluindo que modelos de gestão sustentável podem ser replicados pela história das sociedades.

Palavras-chave: Império Romano. Reino de Portugal. Rio de Janeiro. Gestão das Águas. Sustentabilidade.

\section{INTRODUCTION}

The evolution of man in political, social, economic, historical, or cultural terms should be viewed from the perspective of the historical period of mankind and the division of history into different eras, as a means of creating a background that is conducive to understanding how society itself has evolved.

This evolution can be understood through a division of the past into classical periods and investigating various aspects of society, such as man's first experiences of socializing and living in communities, the first records of artistic and religious expression. It also requires an explanation of the lengthy wars for territory, the creation of currencies, economics, etc. (POMIAN, 1993).

Among examples of the evolution of societies, the Roman Empire can be mentioned as the most powerful empire in the ancient world, reaching $21 \%$ of the world population and capable of developing art, science and politics in a way never seen before. (VALE, 2019).

According to Vale (2019), despite the residential buildings, Ancient Rome stood out because of its great monuments and engineering works, especially: roads, bridges, arches, etc. However, the most important urban project was the implementation of the sanitation system, which included the construction of aqueducts, public cesspools, and the rainwater drainage system.

The concept of drainage can be attributed to a set of implements that could be used for agriculture and were designed to meet the needs of crop irrigation. Following the rise of new civilizations, new drainage models and practices began to be developed, such as the regulation of soil moisture, the alteration of river beds in areas destined for occupation, and practices of collecting and transporting rainwater and wastewater (FERNANDES, 2002).

Man's relationship with water is intricately linked to changes in behaviour which began in the Paleolithic Age among small groups of nomads who later formed larger communities and settled on the land. Setting out from the cultivation of wheat and barley, irrigation techniques emerged which allowed settled communities to move on, initiate a more sedentary life and give rise to the first structured villages.

The Age of Discovery and the Renaissance were closely observed as interconnected phenomena that contributed to the dismantling of the medieval structure and the composing of modern society in Western Europe, promoting the social transformations that influenced the colonized territories (DUTRA, 2013). 
In this historical context, the city of Rio de Janeiro appears as an alternative for Portugal in the face of Napoleonic conquests in the early $19^{\text {th }}$ Century, becoming the capital of the Kingdom of Portugal, Brazil and Algarves between 1815 and 1821, promoting great urban and sanitary transformations (SILVA, 2009).

The content analysis of this study is part of the doctorate research, which seeks to identify a historical correlation between the management models implemented in cities of the ancient Roman Empire and in Rio de Janeiro to justify the influence of societies on issues related to sustainability and water management.

\section{METHODOLOGICAL PROCEDURES}

This research seeks to correlate the historical influence of rainwater management models implemented in the city of Rio de Janeiro by Portuguese colonizers, to models and techniques from the cities of the Roman Empire. The research is conceptualized under a qualitative, descriptive, and interpretive approach to the theme "sustainable rainwater management".

As proposed by Bardin (2011), qualitative content analysis is structured in three stages: organization, coding, and categorization of information, that results in an analytical generalization, capable of allowing the replication of the method, without necessarily requiring quantitative complementation of the theme.

Descriptive research deals with an in-depth analysis of researched reality. It aims to identify correlations between various sources with a focus on the description, classification and interpretation of facts. Assuming that, models or frameworks are proposed from the observation and comprehension of a given phenomenon, which makes them capable of supporting and validating the proposed hypotheses (RUDIO, 1985).

As states Schwandt (1994), an interpretive approach seeks to understand the world from the point of view of those who experience it. It allows understanding the research object as a result of social interaction shaped by the actors involved, through a rereading of the meanings of the phenomena and the observed historical events.

Bardin (2011) defines content analysis as a set of tools of a methodological nature in constant improvement and applied to diverse content and continents.

Data were obtained in the pre-analysis phase through electronic consultation of open access journals available on academic research portals such as BDTD (Digital Library of Theses and Dissertations), ERIC (Education Resources Information Center), Google Books, Google Scholar, JURN, Portal Periodicals Capes, SciELO (Scientific Electronic Library On-line), SCIRUS, SPELL (Scientific Periodicals Electronic Library) and The British Library.

Taking advantage of the option of advanced criteria in the research portals, the authors performed a second search guided by Boolean logic, which deals with a type of information retrieval system, in which two or more terms are combined, relating them by logical operators, and that makes the search more restricted or detailed (FERNEDA, 2003).

The advanced criteria of searching created links between the theme of "sustainable rainwater management" with the ideas of: "Roman Empire" and "Kingdom of Portugal", "Lusitania" and "Roman Empire", "Lisbon" and "Augusta Emerita", "Portugal" and "Age of Discovery", and "Rio de Janeiro" and "Lisbon"; from the use of the operators "and", "or", "and/or" and "not".

Data were compiled using electronic spreadsheets and cross-reference tables which served as input to the NVivo software (version 11). This software was chosen to support the research, performing the tasks of finding, analyzing, and organizing the information in the documents such as scientific papers 
and articles, magazines, newspapers, and web content, according to the relevance and adherence to the theme, whose results can be seen in Table 1 below.

Table 1 | Result of the content analysis of the theme "sustainable rainwater management", according to the relevance and adherence to the links obtained from the advanced search criteria (2010-2020).

\begin{tabular}{lcc}
\hline \multicolumn{1}{c}{ Links } & Number of documents & $\begin{array}{c}\text { Relevance and adherence } \\
\text { to the theme }(\%)^{1}\end{array}$ \\
\hline "Roman Empire" and "Kingdom of Portugal" & 7.315 & 24,59 \\
"Lusitania" and “Roman Empire" & 6.149 & 20,67 \\
"Lisbon" and "Augusta Emerita" & 5.887 & 19,79 \\
"Portugal" and "Age of Discovery" & 3.789 & 12,74 \\
"Rio de Janeiro" and "Lisbon" & 4.125 & 13,87 \\
"rainwater" and "sustainable management" & 2.478 & 8,33 \\
\hline Total of documentary sources & 29.743 & - \\
\hline
\end{tabular}

${ }^{1}$ Percentage determined by the ratio between the total of documents analyzed in a link and the total of documents sources analyzed.

Source: Prepared by the authors, 2021.

The content analysis was linked to the theme "sustainable rainwater management" and resulted in 29,743 documents which were processed by the NVivo software according to the relevance and adherence, which percentage was determined by the ratio between the total of documents analyzed in a link and the total of documents sources analyzed obtained from the advanced search criteria from 2010 to 2020 .

Finally, the content analysis allowed us to include a historical exploration in the literature review of the thesis, to narrow the perception of the influence of the thoughts of ancient societies, and the water management models and practices adopted by the Kingdom of Portugal in Rio de Janeiro.

\section{FROM ANTIQUITY TO THE ROMAN EMPIRE}

According to Morris (1998) - and in contrast with the division of history into classical periods put forward by the Polish historian, Pomian (1993) - the establishment of the first urban civilizations took place during the Bronze Age (3500-3000 B.C.), and lasted for more than 2000 years.

Certain archaeological studies state that the first civilizations arose in the following regions: the South of Mesopotamia (Egypt); the Indus River Valley (Pakistan); the Yellow River (China); the Valley of Mexico; the forests of Guatemala and Honduras; and the coast and plateau of Peru (DANIEL, 1968).

According to Mc-Neill (1998), communities began to be structured as City-States and then displayed political, social, cultural, religious, economic, and urban features and implicit in these radical changes was the most important fact in the history of mankind: the appearance of civilization in the Minoan Civilization (in the Greek island of Crete); in ancient Syria; in Egypt (North-East of Africa) and Sumeria (in lower and mid-Mesopotamia, now the South of Iraq and Kuwait).

The Sumerians (3500 B.C.) increased the extent of irrigated farming because they mastered the techniques of drainage by diverting water from the Tigris River and Euphrates. In this way, they could cultivate vast stretches of alluvial desert and transform a previously arid plain into fertile farmland. Since they were occupying areas that were subject to constant flooding, the Sumerians were compelled to carry out huge engineering works such as large dykes. 
Moreover, to broaden their knowledge of architecture, Sumerians began to build magnificent towns and cities along the riverbanks. These were surrounded by thick walls and inside there were palaces, imposing temples and mansions with walls built of masonry and comfortable houses alongside numerous streets (FERNANDES, 2002).

Similarly, important towns and cities began to emerge along the banks of the Nile River (Egypt) and its plains, which had a surplus agricultural production that was able to support the business activities in the region. The Egyptian civilization was based on a strict social stratification where power was concentrated in the hands of the Pharoah, whereas in the Sumerian civilization power was based on independent City-States (MORRIS, 1998).

Archaeological studies have confirmed that civilization began in the Indus River Valley (3500-1700 B.C.), which comprises an area that includes the North-East of Afghanistan, the greater part of Pakistan and the West and North-West of India. Networks of drainage systems have been discovered in three cities of Harappa, - Mehrgarh and Mohenjo-Daro (Pakistan) and Lothal (India). These were built with great care and were designed to transport rainwater or wastewater and to protect the cities from floodings caused by the thaw that followed the icy season of the Himalayas (WRIGHT, 2010).

New concepts of drainage systems were adopted in these cities at that time, and these involved laying blocks of stones to surround the areas and form elevated walls, to reduce the surface run-off of the rainwater and ensure it could be stored. The rest of the city was built at a lower level and was also surrounded by walls which allowed the citizens to enjoy a rare amenity in ancient times running water. (MORRIS, 1998).

The drainage system adopted in these civilizations was adapted to farming practices and the way the people settled on the river banks so they could make use of the fertility of the alluvial soil for producing food. The growth of agriculture led to an increase in the population and hence, it became necessary to produce more food. This was achieved based on advances made in the technology of drainage systems, since land that had previously been barren, could be used for agricultural purposes.

The Bronze Age witnessed the rise of the island of Crete: the Minoan Civilization (2700-1450 B.C.), with the city of Knossos, where the topography and soil were suited to farming based on the cultivation of wheat and lentils. Owing to its surplus production and its ideal geographical position, the Minoans were able to carry out trade on a large scale with the civilizations of the Western Mediterranean and Eastern Europe (GRAY, 1940).

Among the ruins of the Palace of Knossos, a stonework system was found comprising well-planned towns, cobbled streets, gutters, small shops and residential districts. In addition, the "palace-city" had three separate systems for water management, each of which was designed for supply, drainage of run-off and drainage of wastewater. This system is now recognized as an "absolute separator" and would serve as an inspirational model for the Romans in the future (GRAY, 1940).

Numerous references to water, of every kind of representation, can be found in the history of ancient civilizations, such as cave paintings, records of signs, cultural or religious traditions, etc. In the case of the Persian civilization, rainwater was regarded as sacred and polluting it was a sin. Rainwater was stored in cisterns and used as a source of supply.

Even though there are many different records, the "cradle of civilization" can be regarded as being located in the region of Mesopotamia, which in its etymological origins means a "country situated between two rivers", namely, the Tigris River and Euphrates River - and for the ancient Greeks, this region belonged to the so-called Fertile Crescent (ISSAWI, 1988). 
The rise of the Roman Empire which was responsible for creating one of the greatest civilizations in history can be viewed as one of the finest achievements of mankind. At its peak, it was the most extensive of any empire in the ancient world and its size was never previously witnessed in ancient history.

The domination of Rome (Figure 1), which had a population that reached a million inhabitants lasted for about five centuries (27 B.C. - 476 A.D.) and extended from the Rhine River to Egypt and from Great Britain to Asia Minor, thus forging a link between Europe, Asia and Africa (GIBBON, 1996).

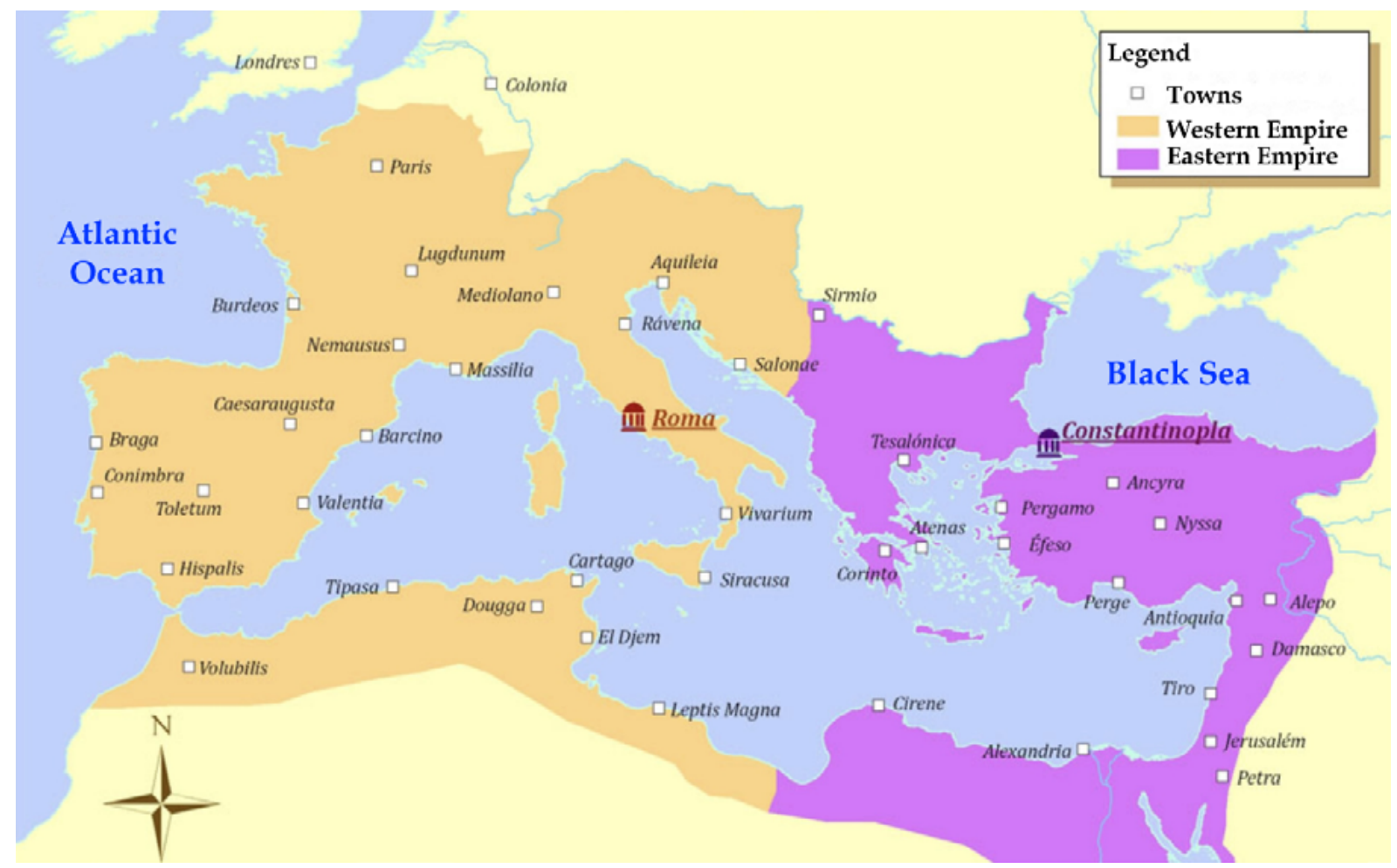

Figure 1 | The Eastern and Western regions of the Roman Empire

Source: Adapted from Gibbon, 2021

In the political system of the Roman Empire power was concentrated in the figure of the emperor from Augustus to Constantine the Great - with the political support of the Senate, which was a legacy of the ancient Roman Republic. As a result of the new system, Rome, a City-State, began to be governed by the emperor and to benefit from technological advances made at that time, from matters related to philosophy and medicine or architecture and engineering.

The Romans built systems of carefully planned roads that included conduits for the surface run-off of rainwater and in this way, they were able to drain their roads. In addition, cisterns were built with communicating chambers and apertures on the roof which were designed to collect and supply water to the cities and ports. The water tanks of that time are an example of how the concepts of hydraulic engineering were preserved (HILL, 1984).

The Romans also built a complex sewerage system made up of open channels and underground ducts for transporting effluent known as "cloaca", the largest of these being the "Cloaca Maxima", which was a public project planned by Etruscan engineers and built by the manpower of the working-class in Rome. This sewerage system was responsible for the drainage of the surrounding region of the Forum extending to the Tiber River (GIBBON, 1996). 


\section{AUGUSTA EMERITA - THE CAPITAL OF LUSITANIA}

When the Eastern region of the Roman Empire was under the rule of Emperor Augustus (27 B.C. -14 A.D.), there was a series of conquests in the European continent which reached Hispanium, the name given by the Romans to the Iberian Peninsula (currently comprising Portugal, Spain, Andorra, Gibraltar, and a small part of the South of France). Hispanium was divided into three provinces (Figure 2): Baetica and Lusitania (Hispania Ulterior) and Hispania Tarraconensis (Hispania Citerior) (LEÃO, 2015).

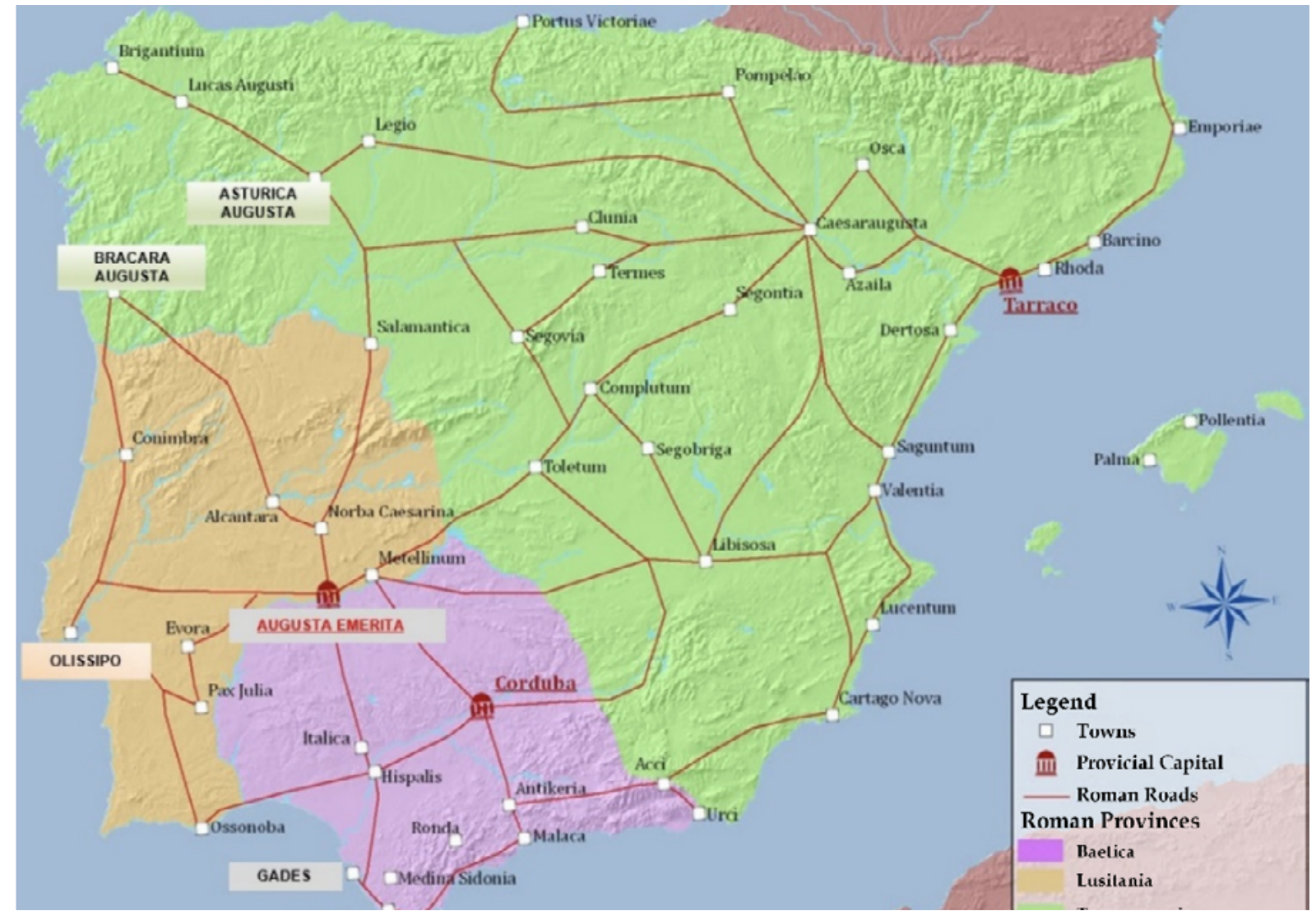

Figure 2 | Hispania (Iberian Peninsula) during the Roman Empire

Source: Adapted from Leão (2015).

Emperor Augustus pursued an expansionist policy to extend Roman domination and founded the following colonies: Augusta Emerita (now Merida) in 27 B.C.; Bracara Augusta (now Braga) in 16 B.C.; Asturica Augusta (now Astorga) in 14 B.C., which had considerable administrative importance as a centre for the control of gold mining; Hispalis (now Seville), and Gades (now Cadiz), from where the gold was shipped to Rome (LEÃO, 2015).

The colony of Augusta Emerita was founded to provide a place for settling war veterans who came from different regions of the Roman Empire. It became the capital of Lusitania since it was a strategic enclave on the banks of the Guadiana River. This meant it could communicate with other colonies through the roads which linked the Baetica province with provinces of the North-East peninsula and with the strips of land in the South of Hispania and the city of Felicitas Julia Olissipo (now Lisbon) (MANTAS, 2004).

Augusta Emerita began to include the essential and indispensable framework required for the institutional facilities of the recently created province of Lusitania: the abode of the magistrates, the public archives, the financial services, etc. Given this, the decision-making of the new colony adopted the regional policies of the Roman Empire and confirmed it was committed to acting as a provincial capital. This entailed following the parameters laid down by the Romans for urban planning and administrative 
responsibilities for the territory and as a result was able to 'romanize' the territorial extension of the Eastern peninsula by reproducing the architectural and urban features of Rome (BORGES, 2016).

Although Augusta Emerita was far away from the splendour of the Italian or Western cities of the Roman Empire and Lusitania was still regarded as a distant province, it was not an isolated territory that was cut off from the Mediterranean world. The economic and strategic importance of Lusitania and its provincial products meant that it stood out from the other Roman colonies (MANTAS, 2004).

It should be noted that the growth of the towns and cities in Lusitania had to be accompanied by irrigation techniques, hydraulic engineering and Roman architecture. This made Augusta Emerita a showcase for the Roman Empire since the principle of urbanism that was instilled in that colony as a dominance strategy, enabled the process of "romanization" to become widespread and the concepts of imperial power and culture to be merged in the region of Hispania (BORGES, 2016).

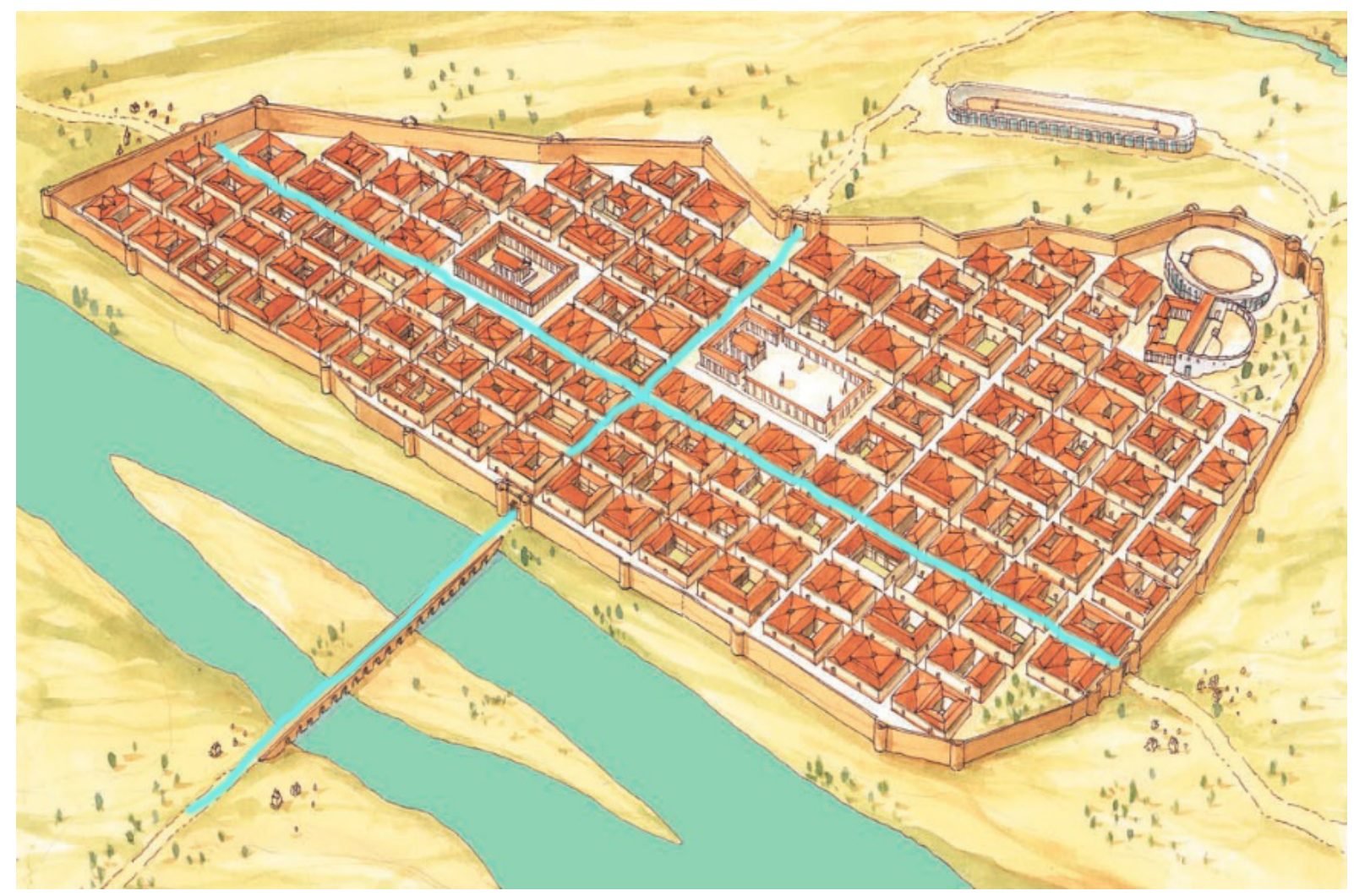

Figure 3 | Artistic representation of Augusta Emerita

Source: Adapted from Rome on Rome, 2021

Figure 3 (above) is a representation of Augusta Emerita when it became one of the main towns of Roman Hispania with an area of about $20.000 \mathrm{~km}^{2}$ and its water distribution system followed the models employed in Rome. It involved the building of dams (the Proserpina and Cornalvo dams) and aqueducts (Aqueduct of Los Milagros, Acqua Augusta and Rabo de Buey-San Lazaro), as well as bridges and arches, which allowed water to be distributed from the spas and springs of the city (LEÃO, 2015).

Thus, it is worth underlining the importance of Felicitas Julia Olissipo (now Lisbon). During the period of Roman domination, it became a maritime centre for the Atlantic Ocean. This was because the estuary of the Tagus River gave protection to the ships, provided access to deep-draught embarkation, as well as offering a means of communicating with the interior of the peninsula. In addition, the maritime route from Cadiz to Lisbon allowed agricultural products to be transported from the Guadalquivir River valley 
to regions in the north and middle of Hispania, thus strengthening the ties between the Mediterranean world and the Atlantic Ocean (MENDES, 2014).

The end of Roman Hispania Romana was brought about by the weakening of the Roman Empire around 255 A.D., when there were invasions from the South by the Vandals, from the North of Lusitania by the Swabians and the centre of the region by the Alans. Most of the towns of Europe shrank in size when their residents fled from the urban centres where there was insecurity and a state of anarchy. This was followed by robbery and plunder as the outskirts and rural areas became occupied, resulting in mass emigration (BISHOP, 1968).

Rome attempted to re-establish order in Hispania by forming a truce with the Visigoths, but this soon became unstuck on account of the excessive taxes levied by the decadent Empire. After the disappearance of the Roman institutions, the Swabians, followed by the Visigoths, adopted an ecclesiastical system as their administrative model, which was a means of ensuring stability and established one of the first Christian kingdoms in Europe (BARBERO; LORING, 2005).

The Swabians and Visigoths filled in the power vacuum left by the Roman administrators and thus maintained their standards with a high degree of centralized power in their capitals, Braga and Toledo, respectively. Despite their fall from power, Roman law remained in the Visigoth Code and Hispania maintained the infrastructure of the cities such as roads, bridges, aqueducts and irrigation and drainage systems (BARBERO; LORING, 2005).

The dominance of the Visigoths ended with the Islamic invasion of the Iberian Peninsula - the so-called Arab Conquest - when troops coming from North Africa crossed the straits of Gibraltar (711-726 A.D.), resulting in serious population displacements and the conquest of the peninsula (AFONSO, 1972).

The Moors governed the peninsula for 800 years after seizing the territory that they called "al-Andalus", because of their military and territorial dominance and this led to a blending of peoples and cultures of very heterogeneous social origins. However, they kept the main part of the Roman legacy, by repairing and extending the inherited infrastructure and making use of it for irrigation while introducing new farming practices and new products, such as rice, sugar cane, citrus fruit, apricots and cotton (CHACON, 2005).

The "Reconquest" - as some historians dubbed the attack against the Moors - was concluded at the beginning of the Modern Age when the Catholic monarchs, Fernando of Aragon and Isabel of Castile, brought about the final expulsion of the Moslems, in 1492. However, the Moors left the Iberian Peninsula a valuable cultural heritage and progressive scientific knowledge which was characterized by their architecture and naval engineering which would contribute to the founding of the future empires established by the Portuguese and Spanish discoveries (LOMAX, 1978).

\section{THE KINGDOM OF PORTUGAL AND THE AGE OF DISCOVERY}

The features of Felicitas Julia Olissipo were radically changed by the crisis in Roman society and the physiognomy underwent great alterations, mainly due to the conquest of the Visigoths. They gave the name of "Ulishbon" to the main port, and this was subsequently altered by the Arabs to "Lušbūna" or "al-Ushbuna", which is now called Lisbon [Lisboa] (SILVA, 2008).

After the reconquest of the Iberian Peninsula and the founding of the Kingdom of Portugal in the $12^{\text {th }}$ Century, D. Afonso Henriques - the first king of Portugal - began to administer the new socio-economic policies based on the feudal system and Lisbon replaced Coimbra as the capital of the kingdom and most important city in the region. 
At that time, water was an essential element in economic development and, thus, windmills and watermills were designed to act as the mainspring for grinding corn, weaving, dyeing, and tanning - all activities that had profound effects on the properties of the feudal lords.

The region of Lisbon had a large population and there was a constant problem caused by the scarcity of drinking water, despite the presence of the Tagus River, which had high levels of salinity that made the water unsuitable for human consumption. The only district of Lisbon with available springs was Alfama, so this meant it was necessary to obtain water from far away places like the ravine of Ribeira de Carenque, in the region of Belas, where the water had been used by the Romans, who had built a dam and an aqueduct there (CASEIRO, 1999).

As states, Caseiro (1999), the Aqueduct of Free Waters [Aqueduto das Águas Livres] is a complex stonework system for the intake, adduction, and distribution of water, and this supplied water to the city of Lisbon through a network of fountains and water sources through the force of gravity and comprised a total of approximately $58 \mathrm{~km}$ of underground tunnels and upper galleries.

During this period, Portugal became the leading navigational power in the world and was a pioneer in so far as it was the first country to transform the discoveries of technological and scientific research into State policies. In this way, it paved the way for Aragonese and Catalans, to enhance the nautical knowledge of the naval officers and simple sailors which culminated in, for example, the discovery of the archipelagos of the Azores, Madeira and the Canary Islands, Brazil in South America and a vast territory in Asia (CHACON, 2005).

In the history of Lisbon, an earthquake followed by a tsunami, and the outbreak of fires that occurred on $1^{\text {st }}$ November 1755 , destroyed most of the city. Curiously, the Aqueduct of Free Waters was not affected by the seismic event. King D. José I granted absolute powers to Sebastião José de Carvalho e Melo, the future Marquis de Pombal, who restored the city by employing engineers and architects to undertake a work of urban regeneration (TAVARES, 2005).

The reconstruction of Lisbon was funded by the wealth of the colonies, particularly Brazil where excessive taxes were levied in exchange for special privileges such as the granting of lease contracts and royal bounties, giving the elite the most profitable trading concessions of the Crown (ROMEIRO; BOTELHO, 2003).

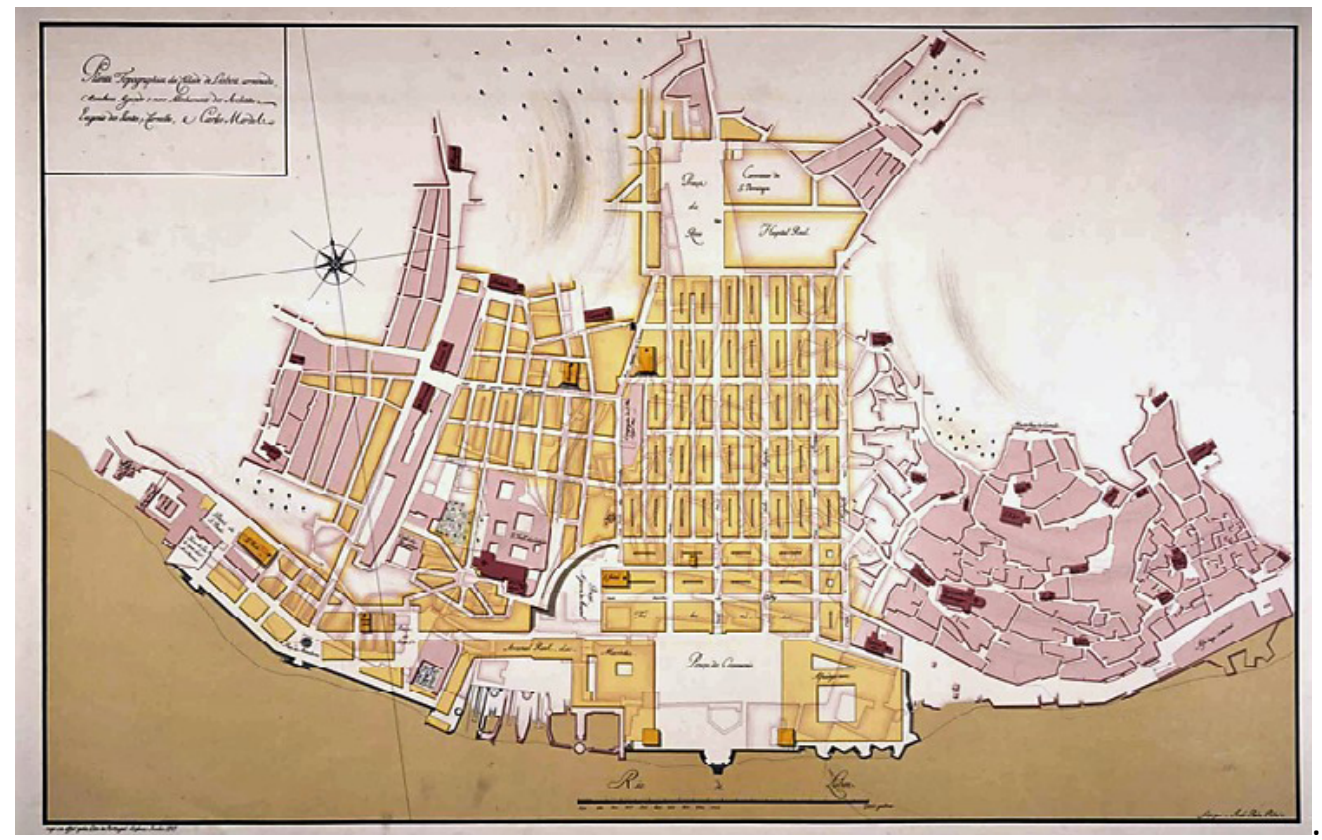

Figure 4 | "Pombaline" Lisbon Source: Adapted from Museum of Lisbon (2021) 
The plan to reconstruct Lisbon followed the pattern of a checkered outline (Figure 4) which extended from Rossio Square to Terreiro do Paço and included the streets alongside the Tagus River and architecture based on rational concepts and the ideas of the Enlightenment which were becoming widespread at that time (FONSECA, 2005).

The sanitary sewage system and the means of distributing water were redesigned to cater to the needs of the modern city that had arisen. These were based on the new methods of calculating the speed of the surface run-off and leaks that emerged in the Modern Age and survived into the $19^{\text {th }}$ Century. Moreover, it was established that rivers, springs and underground waters were formed from rainwater. (FONSECA, 2005).

\section{RIO DE JANEIRO - THE CAPITAL OF PORTUGAL}

At the beginning of the $19^{\text {th }}$ Century, a large part of Europe was under the dominion of France and governed by Napoleon Bonaparte, proclaimed emperor in 1804. The main strategy of the French government was the Decree of the Continental Blockade in 1806, which brought into effect a largescale trade embargo against the British Isles.

However, the government of Portugal was reluctant to adhere to the Blockade on account of its longstanding traditional ties with England on which it depended a great deal economically. The Prince Regent Dom João VI was in a delicate situation and "was uncertain about which alternative strategy would be most damaging to the Portuguese monarchy" (MATTOS, 2017).

The everyday life of Lisbon was greatly affected by the rumours of an imminent French invasion and there was an increasing sense of insecurity. For this reason, a planned course of action began to gather momentum - to transfer the court of the Portuguese monarchy to Brazil. In light of this, a strategic plan of escape was put into effect on the morning of $29^{\text {th }}$ November 1807, when the Prince Regent went on board the Nau Capitânia, and accompanied by English vessels, finally left Lisbon on course for Rio de Janeiro (MATTOS, 1995).

The arrival of the Portuguese Royal Family in Rio de Janeiro, at the beginning of the 19th Century, was a significant social event and led to radical changes which were aimed at turning the colonized city into a metropolis. The Prince Regent promulgated the Royal Charter for the Opening of Ports to Friendly Nations [Carta Régia de Abertura dos Portos às Nações Amigas] four days after his arrival and as a result of this act, Brazilian towns and cities began to acquire great social and economic importance since it meant the end of the Colonial Pact and allowed freedom of trade with other countries (MATTOS, 1995).

The choice of Rio de Janeiro followed key criteria because it was the most populous and economically important Brazilian city, as well as having a wealthy elite of traders and a powerful naval industry. In addition, Rio de Janeiro was endowed with a reasonable system of defence since it housed a large military contingent of captaincies and was one of the headquarters of the Portuguese naval squadrons in Brazil (CAVALCANTI, 2004).

In 1808, approximately 865 vessels went to the port of Rio de Janeiro filled with merchandise and an assortment of novelties of various nationalities which represented a significantly large number for that time. On the other hand, the Europeans were dazzled by the exoticism of the natural surroundings, while on the other they were frightened of the urban crowds flocking around them (SILVA, 2009).

As well as changes in architecture and engineering, the new features introduced or inspired by $D$. João VI included the foundation of the Imperial School of Arts and Crafts, the French Artistic Mission, the Royal Printing Press, the National Library, the Botanical Gardens, the Military Archives, the Naval Academy, the Bank of Brazil, and the Munitions Factory, as well as newspapers, schools, museums, theatres, etc. (HEYNEMANN; VALE, 2010). 
A decree was promulgated for the Supervision of Court Police on $10^{\text {th }}$ May 1808 , which was a public body with responsibilities like those currently carried out by the City Council. In a similar way to its counterpart in Lisbon, the body began to be responsible for the following: security, criminal investigation, arresting criminals undertaking public works, protecting supplies, and dealing with matters linked to public order (HEYNEMANN; VALE, 2010).

The urban space of Rio de Janeiro was altered in a relatively short time under the command of the Conde dos Arcos, who was the last viceroy of Brazil. The old streets which had previously been bumpy and neglected were covered in new paving to make it easier to travel in carriages, which now began to appear in all directions. The streets and roads were open so there could be a surface runoff and allow the products grown in areas close to the city to be transported to meet the needs of the Court. Public lighting began to appear throughout the city, and whale oil was used in the lampposts, squares and public gardens which led to an alteration in the everyday lives of locals. (SILVA, 2009).

The water resource management of the city was under the command of the Parliamentary Chamber. This applied the principles inherited from the engineers and architects who had been responsible for the reconstruction of Lisbon. They formed landfills and drained many swamps such as the Campo de Santana, which operated as a dumping ground and had large cesspits and ditches.

The system for supplying water in Rio de Janeiro consisted of the aqueduct and fountain of Carioca and was extended through the construction of new bridges, springs and fountains, as well as by increasing the capacity of the already existing Chafariz do Carmo. (HEYNEMANN; VALE, 2010).

Rio de Janeiro was the capital of the Kingdom of Portugal, Brazil and the Algarves between 1815 and 1821, when D. João VI returned to Portugal, leaving an altogether different city to be governed by his son D. Pedro de Alcântara - D. Pedro I (SILVA, 2009).

\section{SUSTAINABILITY - A HISTORICAL PROCESS}

The influence of ancient societies went beyond the limits of culture, language, religion, and arts, and reached the thoughts of public administrators who formalized policies aimed at the domain of the territory and economic development (POMIAN, 1993).

The action of people on nature, since the most primitive society, has resulted in environmental degradation, under the justification of the need to produce food, consumer goods, energy, build cities, etc. In this process, water has always been the most important natural resource, generating conflicts of interest that did not exist until then.

There are some records from antiquity reporting the concern of some public administrators in the preservation of forests as regulators of the water cycle and in protecting soils against erosion, such as the writings of Plato in 4 B.C. complaining about the devastation of landscapes in Greece (BORGES; MARCÍLIO, 2021).

During the period of development of territories and cities, environmental sustainability never had its importance considered in the management and the urbanization models implemented, and its importance was given through a long historical process, going from the "conqueror" to the "conquered", small ecological practices and sustainable experiences replicated in each region, according to its characteristics. 


\section{FINAL CONSIDERATIONS}

As the result of doctorate reflections, this article presents a theoretical discussion on the influence of the thoughts of ancient societies. This analytical-discursive research allowed us to observe a historical correlation between management models implemented in cities of the ancient Roman Empire and Rio de Janeiro.

The content analysis carried out under the methodology described by Laurence Bardin created links between the theme "sustainability" and "rainwater management" with the historical contribution of Portuguese colonization, from the Roman domination to the arrival of the Royal Family in Rio de Janeiro, including the Moorish domain of the Iberian Peninsula.

Analyzed data confirmed that the Roman culture significantly influenced the Mediterranean world, constituting a solid model for the entire Western civilization, as attested by Locatteli and Schörner (2009). This observation allowed us to verify the relevance of studying the history of ancient civilizations for understanding the models inherited by the current contemporary society.

It can be concluded that the influence of the ideas of societies, referring to politics, culture, art, architecture and engineering cut across time and space. Thus, they can allow progress to be made in terms of innovative ideas and engineering techniques that are strengthened by traditional knowledge and can alter the environmental conditions where they prevail.

In addition, the relationship between the models for water management adopted and put into effect by the Kingdom of Portugal, and the techniques for the intake, storage and supply of water and sewage disposal were inherited from the Roman Empire. Years later, they crossed the Atlantic Ocean with the Portuguese Royal Family and changed the way of life and standard of living of the inhabitants of Rio de Janeiro.

Finally, it can be concluded that the process of raising heightened awareness and alteration of the characteristics of the water system must be continuous. Moreover, the inclusion of the historical background and social participation should be regarded as a positive factor in ensuring the improvement and success of the models for water resource management in any region.

\section{REFERENCES}

AFONSO, A. M. Curso de história da civilização portuguesa. Porto: Porto Editora, 1972.

BARBERO, A.; LORING, M. I. The formation of the Sueve and Visigothic kingdoms in Spain. Cambridge: Cambridge University Press, 2005.

BARDIN, L. Análise de conteúdo. São Paulo: Edições 70, 2011.

BISHOP, M. The Middle Ages. Boston: Houghton Mifflin Company, 1968.

BORGES, A. S. A paisagem imperial em cidades da Lusitânia: um estudo comparado das formas de integração da elite provincial entre os séculos I a.C. e III d.C. 2016. 491 p. Tese (Doutorado em História) - Universidade Federal do Rio de Janeiro, Rio de Janeiro, 2016.

BORGES, R. M. de M.; MARCíLIO, T. G. A ética em Platão. In: Revista Ambiental em Ação [on-line], vol. XX, n. 75, jun-ago 2021. Avaiable at: https://www.revistaea.org/artigo.php?idartigo=4151. Accessed: 27 jul. 2021.

CASEIRO, C. Histórias e outras memórias do Aqueduto das Águas Livres. Lisboa: Epal, 1999. 
CAVALCANTI, N. O Rio de Janeiro setecentista: a vida e a construção da cidade da invasão francesa até a chegada da corte. Rio de Janeiro: Jorge Zahar, 2004.

CHACON, V. A grande Ibéria: convergências e divergências de uma tendência. São Paulo: Editora Unesp, 2005.

DANIEL, G. The first civilisations: the archaeology of their origins. London: Thames and Hudson, 1968.

DUTRA, D. P. de S. A cultura dos descobrimentos em Portugal: um estudo da relação entre a sabedoria do mar e o conhecimento acadêmico na Renascença. 2013. 122 p. Dissertação (Mestrado em História) - Universidade Federal Fluminense, Niterói, 2013.

FERNANDES, C. Microdrenagem: um estudo inicial. Campina Grande: Publicação DEC/CCT/UFPB, 2002.

FERNEDA, E. Recuperação da informação: análise sobre a contribuição da ciência da computação para a ciência da informação. 2003. Tese (Doutorado em Comunicação e Arte) - Universidade de São Paulo, São Paulo, 2003.

FONSECA, J. D. 1755 - 0 terramoto de Lisboa. Lisboa: Argumentum Edições, 2005.

GIBBON, E. The history of the decline and fall of the Roman Empire. v. 1 \& v. 2. London: Penguin Classics, 1996.

GRAY, H. F. Sewerage in ancient and mediaeval times. Sewage Works Journal, Water Environment Federation, Alexandria, VA, p. 939-946, 1940.

HEYNEMANN, C. B.; VALE, R. W. S. do (Org.) Temas luso-brasileiros no Arquivo Nacional. Rio de Janeiro: Arquivo Nacional, 2010.

HILL, D. A history of engineering in classical and medieval times. London: Croom Helm Ltd., 1984.

ISSAWI, C. P. The Fertile Crescent (1800-1914): a documentary economic history. New York: Oxford University Press, 1988.

LEÃO, N. M. de. Influências greco-romanas na hispânia: colonização, arquitetura e urbanismo de Emerita Augusta (séculos I a.C. ao II d.C.). 2015. 287 p. Dissertação (Mestrado em História) - Pontifícia Universidade Católica do Rio Grande do Sul, Porto Alegre, 2015.

LOCATTELI, F.; SCHÖRNER, A. História antiga: um legado contemporâneo. In: Anais da SIEPE - Semana de Integração Ensino, Out. 2009.

LOMAX, D. W. The Reconquest of Spain. London: Longman, 1978.

MANTAS, V. G. A Lusitânia e o Mediterrâneo: identidade e diversidade numa província romana. In: Revista de Arqueologia, v. 43, p. 63-83, Conimbriga, 2004.

MATTOS, I. R. de. O Rio de Janeiro, capital do reino. São Paulo: Atual Editora, 1995.

MATTOS, I. R. de. O tempo Saquarema. A formação do Estado Imperial. São Paulo: Hucitec, 2017.

MC-NEILL, W. H. Plagues and peoples. New York: Anchor Books Editions, 1998.

MENDES, N. M. A província da Lusitânia: sistema econômico global e local. In: Revista do Museu de Arqueologia e Etnia, p. 49-58, Universidade de São Paulo, São Paulo, 2014. 
MORRIS, A. E. J. Historia de la forma urbana: desde sus orígenes hasta la revolución industrial. Barcelona: Editorial Gustavo Gili, 1998.

MUSEUM OF LISBON. Pombaline Lisbon: the 1755 earthquake and the reconstruction. Available at: https://www. museudelisboa.pt/pt/colecoes/gravura/planta-topografica-da-cidade-de-lisboa Acessed: 30 jun. 2021.

POMIAN, K. Periodização. Imprensa Nacional, Casa da Moeda, Lisboa, v. 30, p. 164-213, 1993.

ROMEIRO, A.; BOTELHO, A. V. Dicionário histórico das Minas Gerais. Período colonial. Belo Horizonte: Autêntica, 2003.

RUDIO, F. V. Introdução ao projeto de pesquisa científica. Petrópolis: Vozes, 1985

SCHWANDT, T. A. Constructivist, interpretivist approaches to human inquiry. In: DENZIN, N. K.; LINCOLN, Y. S. (Ed.) Handbook of qualitative research. Thousand Oaks: Sage, 1994. p. 118-137.

SILVA, C. G. da. Lisboa medieval: a organização e a estruturação do espaço urbano. Lisboa: Colibri, 2008.

SILVA, M. A. D. da. A Família Real no Rio de Janeiro: doenças e práticas terapêuticas no período joanino. Rio de Janeiro: Casa de Oswaldo Cruz, 2009.

TAVARES, R. O pequeno livro do grande terramoto. Lisboa: Edições Tinta da China, 2005.

VALE, P. S. O que a Roma Antiga tem para ensinar às metrópoles brasileiras? Electronic publishing at Caos Planejado. Gestão Urbana Economia. Mai. 2019. Avaiable at: https://caosplanejado.com/o-que-a-roma-antigatem-para-ensinar/ Acessed: 30 jun. 2021

WRIGHT, R. P. The ancient Indus: urbanism, economy, and society. Case studies in early societies. Cambridge: Cambridge University Press, 2010. 